\title{
Finger Imprint of Poncirus trifoliata: A Specific Interaction of a Viroid, a Host, and Irrigation
}

\author{
G. Vidalakis, D. J. Gumpf, J. A. Bash, and J. S. Semancik, Department of Plant Pathology, University of Califor- \\ nia, Riverside 92521
}

\begin{abstract}
Vidalakis, G., Gumpf, D. J., Bash, J. A., and Semancik, J. S. 2004. Finger imprint of Poncirus trifoliata: A specific interaction of a viroid, a host, and irrigation. Plant Dis. 88:709-713.
\end{abstract}

The unusual symptom, "finger imprint", described exclusively on Poncirus trifoliata, has been reported in only a single field trial investigating the effects of citrus viroids on crop performance. With this, the question has persisted whether the observed growth abnormality was a disease symptom induced by Citrus viroid IIIb (CVd-IIIb) or a consequence of mechanical damage caused by the handling of young trees during propagation or cultural practices in the field. The recurrence of finger imprint symptoms on trees after 5 years in the field in which no abnormal growth features were previously noted now supports the proposition of a viroid-induced disease. The symptom expression results from an unusual etiology of a complex relationship of the specific viroid CVd-IIIb on the specific rootstock $P$. trifoliata only when supplemental water is applied by sprinkler irrigation.

Additional keywords: citrus disease, citrus dwarfing

Five distinct viroids representing three genera of the Pospiviroidae family have been identified in citrus (3). Only two diseases of economic impact, exocortis caused by the Pospiviroid, Citrus exocortis viroid (CEVd) (7), and cachexia caused by the Hostuviroid, Citrus viroid IIb (CVdIIb) (19), have been attributed to these small, transmissible, single-stranded, circular RNA molecules. However, a diverse symptomatology including bark cracking, gumming, stem pitting, leaf epinasty, petiole and leaf tip browning, vein necrosis, and dwarfing have been attributed to viroid infection of various citrus species (5). Symptom expression induced by the two citrus viroids belonging to the genus $A p$ scaviroid, Citrus viroid I (CVd-I) or Citrus bent leaf viroid (CBLVd) (2) and Citrus viroid III (CVd-III) (12), are notable because of the highly restricted host ranges of these viroids to Citrus species, with the exception of the unusual transmission of CBLVd to avocado by heterologous grafting (8).

The single reported occurrence of an unusual symptom on Poncirus trifoliata rootstock, "trifoliate finger imprint", was observed on field trees infected with CVdIIIb (13). The symptom, characterized by indented imprints and horizontal striations

Corresponding author: J. S. Semancik

E-mail: Semancik@ucr.edu

Accepted for publication 26 February 2004.

Publication no. D-2004-0426-01R

(C) 2004 The American Phytopathological Society resembling a constriction of the trunk, was initially observed on 8- to 10-year-old trees with Valencia orange scions. With succeeding growth, the symptoms did not intensify, and an apparent healing or moderation of the symptom occurred. Thus, it has been speculated that the symptom might have been a result of tree damage at some time during propagation and handling prior to field planting or subsequently in field management. The only similar disorder reported in citrus is "finger marks", an abnormality that affects scion branches in several citrus cultivars (10). Although a relationship to concavegum psorosis was suggested, transmission of this disorder has not been demonstrated.

A field trial was established in 1998 at the same location and with plant materials similar to the single trial from which "finger imprint" was originally described. The designed purpose of this trial was not to reproduce finger imprint symptoms but to evaluate tree size and fruit yield and quality in trees with CVd-IIa, a noncachexia variant of CVd-II that causes bark cracking on $P$. trifoliata (13), and CVd-IIIb, known to induce dwarfing of citrus scions on $P$. trifoliata (17). The growth of Washington navel orange scion on trifoliate rootstock was normal for the first 5 years in the field. Subsequently, while the scion growth remained normal, the finger imprint syndrome appeared specifically on the trifoliate rootstocks containing CVd-IIIb. More critical observations of field conditions and testing of plant tissues for viroid titer have been reviewed in an effort to confirm the response as a disease symptom and to better define the conditions that promote the development of the trifoliate finger imprint symptom.

\section{MATERIALS AND METHODS}

Plant culture and viroid inoculation. Washington navel scion was budded to $P$. trifoliata cv. Rich 16-6 and Carrizo citrange $(P$. trifoliata $\times$ Citrus sinensis $)$ rootstock seedlings. All buds were taken from registered trees that had tested negative for all known graft transmissible citrus pathogens. Viroid inoculation was accomplished by graft inoculation from viroid reservoir trees of Valencia orange containing either CVd-IIa or CVd-IIIb. Following 1 year of maintenance under standard greenhouse conditions, a minimum of eight trees per treatment with each rootstock was field planted at the University of California Lindcove Research and Extension Center in Tulare County. Trees were established in a field of uniform quality under standard conditions for central California that included sprinkler irrigation. During late spring to early fall, supplemental water of 150 to 375 liters/tree/week (40 to $100 \mathrm{gal} /$ tree/week) was administered through Bowsmith fan jet $1 / 2$ circle pattern sprinkler heads delivering about 40 liters/h (10 $\mathrm{gal} / \mathrm{h})$ when operated at a pressure of $30 \mathrm{psi}$.

Viroid identification by imprint hybridization. Samples from finger imprint symptomatic trifoliate rootstocks were collected in June 2003. Bark tissue from four trees was removed as a strip of approximately $4 \times 20 \mathrm{~cm}$. These samples included, as a single continuous section, a portion of the scion and rootstock tissues extending from the normal rootstock tissue above the finger imprint continuing through the symptomatic finger imprint area to normal tissue below the symptom.

Cross sections of specific areas of these bark strips were used for direct assay by imprint hybridization and as inoculum sources for detection of viroid infection by bioamplification in citron (Citrus medica). The bark strips were assayed from areas of the scion, finger imprint, and the unaffected area of the rootstock. Multiple imprints from freshly cut cross sections of the bark were produced by firm pressure onto positively charged nylon membrane. Similar tissues from the same bark samples were used for graft inoculation of citrons. Stem sections of citrons were subsequently also assayed for CVd-IIIb by imprint hybridization 6 to 12 weeks postinoculation. 
The imprints of the citron stems were hybridized against a CVd-IIIb digoxigenin (DIG) labeled DNA probe. The hybridization procedure included a 10 -min treat- ment of the membrane with a $2 \mathrm{M}$ solution of 2-mercaptoethanol, a prehybridization step of $2 \mathrm{~h}$ at $50^{\circ} \mathrm{C}$, and an overnight hybridization step at the same temperature.
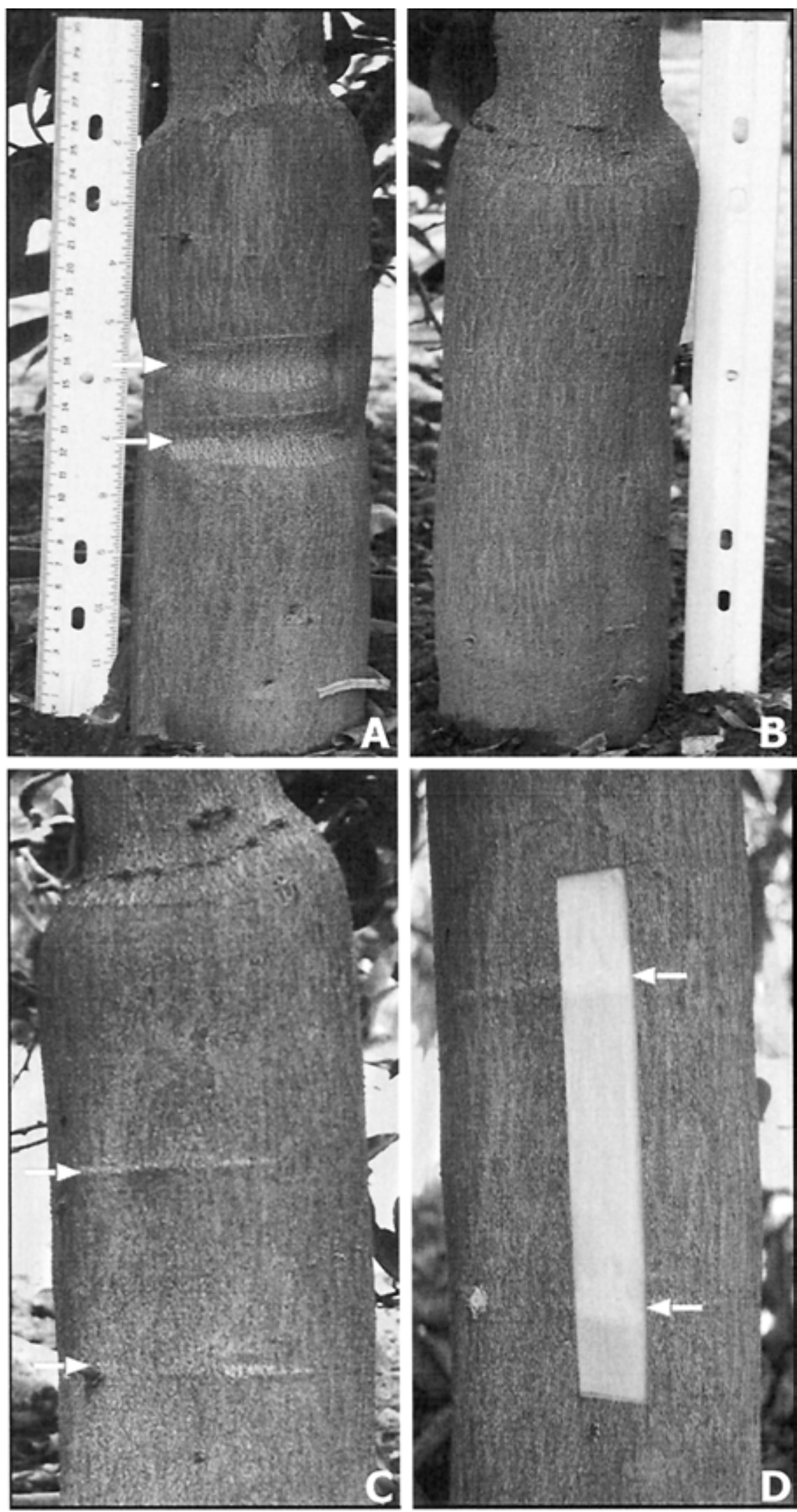

Fig. 1. Poncirus trifoliata rootstock with $\mathbf{A}$, symptoms of finger imprint and $\mathbf{B}$, the nonsymptomatic opposite side of the same tree. $\mathbf{C}$, Striations on the bark surface and $\mathbf{D}$, exposed underlying wood from the same tree magnified.

Membranes were washed at $60^{\circ} \mathrm{C}$ for $1 \mathrm{~h}$, and positive hybridizations were detected after the addition of alkaline phosphatase conjugated DIG antibodies in solution (1:5,000 dilution) and the chemiluminescent substrate CSPD at room temperature (11). A modified protocol that included a longer hybridization time of $48 \mathrm{~h}$ at reduced temperature of $45^{\circ} \mathrm{C}$, addition of a second aliquot of probe after the first $24 \mathrm{~h}$, and reduction of the washing temperature to $50^{\circ} \mathrm{C}$ was employed with the bark imprint membrane.

\section{RESULTS}

Variation in symptoms expressed by $P$. trifoliata in the presence of CVd-IIIb. Seedlings of $P$. trifoliata budded with Washington navel sweet orange scions and inoculated with CVd-IIIb displayed no abnormal growth characteristics during the 1- to 2-year period required for greenhouse propagation and for the initial 4 to 5 years in the field. However, after 5 years of field growth, obvious symptoms of severe finger imprint (Fig. 1A) and bark striations (Fig. 1C) were observed on 37 of 38 trees with the same treatment. The most predominant and severe pattern observed was a "paired" finger imprint (Fig. 1A). Although the bark striations were mild, traces could be observed on the underlying wood exposed by peeling the bark (Fig. 1D). In many cases, the bark striations resemble the upper limit of the finger imprint symptom in which the severe groove pattern had failed to develop (Fig. 1A and C). Since in a number of cases a combination of the finger imprint and bark striation symptoms could be observed on a single rootstock, both symptoms were considered to be expressions of the same syndrome.

Orientation of symptoms and association with water management. A curious feature of the symptoms was the highly sectored nature of appearance. Rootstocks displaying very pronounced symptoms of finger imprint, as in Figure 1A, were completely unaffected on the opposite side of the tree at the same level as the imprint symptom (Fig. 1B). However, a direct correlation in 27 of 38 trees included in the treatment could be made between the orientations of the finger imprint or bark striation symptoms and the position of the adjacent irrigation sprinkler head (Fig. $2 \mathrm{~A})$. This value increased to $83 \%$ of those trees displaying the most severe finger imprint symptoms. A similar correlation could not be made between the loci of symptom development with any other factor, including geographic orientation, that might have resulted in differential climatic conditions on localized areas of the tree.

A common cultural practice in this major citrus growing region is to position the sprinkler head in close proximity to the newly planted trees to assure an adequate water supply in the area of new root devel- 
opment. With this positioning, the sector of the rootstock adjacent to the sprinkler head is regularly wet, whereas the opposite side is less often moistened and may even remain completely dry. Other similar field trials of older age and with identical plant materials in which water was applied by furrow irrigation have never expressed the finger imprint symptom (J. S. Semancik, unpublished data). The association of this syndrome with sprinkler application of water is further supported by the apparent "healing" or moderation of the severe symptoms found to coincide with the movement of sprinklers at a distance between the established trees resulting in no direct contact of the supplemental water and the rootstocks.

Viroid association with affected tissues. As with the bark striations, obvious traces of the imprints were found extending into the wood (Fig. 2B). Detection of CVd-IIIb in specific sites within the symptomatic rootstock tissues was made by imprint hybridization of cross sections from peeled bark of the finger imprint area (Fig. 3A). The presence of CVd-IIIb in the cambial area was detected in bark from the scion and the unaffected rootstock area but not in the area of the finger imprint constriction itself (Fig. 3B).

However, evidence for the presence of the viroid in all tissues assayed was obtained by graft inoculation of rootstock and scion bark to citron. Imprint hybridization of inoculated citron apex stem tissues indicated that the viroid was present in both symptomatic and nonsymptomatic areas of the rootstock (Fig. 3C). From these analyses, it can be speculated that although the viroid is present in both scion and rootstock, the titer of CVd-IIIb within the imprint is much lower than in the normalappearing rootstock tissue bordering the symptom.

Characteristics of vegetative growth of viroid infected trees. Estimates of volume of vegetative growth of scion tissues were made to determine if the finger imprint symptom on the rootstock was correlated with canopy size. Included within the same field trial were the additional treatments of infection with CVd-IIa and the trifoliate hybrid rootstock, Carrizo citrange, budded with Washington navel scion. A comparison of the effect of CVdIIa and CVd-IIIb on symptom expression on P. trifoliata and citrange rootstock and the associated vegetative growth of the scion are presented in Table 1. Although some reduction of vegetative growth on $P$. trifoliata rootstock is observed with the introduction of both CVd-IIa and CVdIIIb, the finger imprint and bark striation symptoms are specific for CVd-IIIb. However, no scion reduction or symptoms are displayed on the trifoliate hybrid rootstock Carrizo citrange containing CVd-IIIb, indicating the specificity of $P$. trifoliata for expression of the finger imprint symptom.
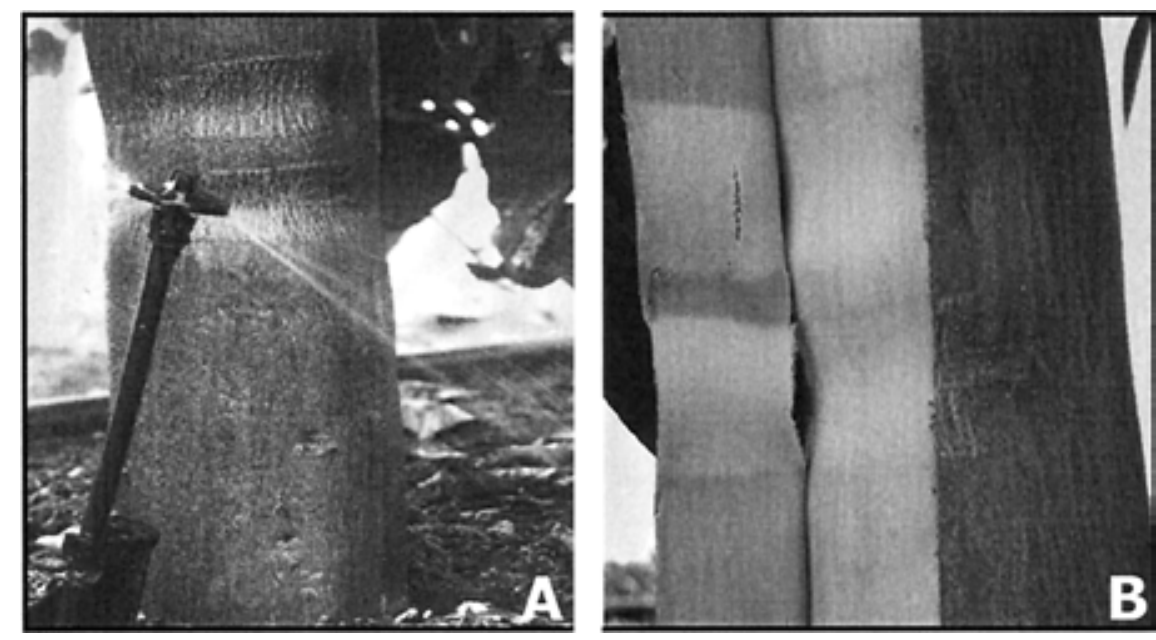

Fig. 2. A, Proximity of irrigation sprinkler emitter to the area of finger imprint symptoms on Poncirus trifoliata rootstock and $\mathbf{B}$, impressions produced on the underside of bark and exposed wood.



Fig. 3. A, Poncirus trifoliata rootstock bark peeled from area of scion and finger imprint symptom in the rootstock (top to bottom). B, Imprint hybridization of (i) cross sections through scion, (ii) nonsymptomatic rootstock area, and (iii) finger imprint constriction, with positive hybridization reaction indicated by white arrow. $\mathbf{C}$, Imprint hybridization of cross sections from stems of citron (Citrus medica) inoculated with (i) bark tissues from scion, (ii) nonsymptomatic rootstock, and (iii) area of finger imprint constriction. (iv) Control reactions from healthy (left) and Citrus viroid IIIb-infected citrons (right). 
Table 1. Symptoms and vegetative growth expressed as canopy volume of Washington navel orange scions associated with the presence of Citrus viroid IIa (CVd-IIa) and Citrus viroid IIIb (CVd-IIIb) on Poncirus trifoliata and Carrizo citrange rootstocks

\begin{tabular}{|c|c|c|c|c|}
\hline \multirow[b]{2}{*}{ Treatment } & \multicolumn{2}{|c|}{ P. trifoliata } & \multicolumn{2}{|c|}{ Carrizo citrange } \\
\hline & Symptom $^{a}$ & Scion vol. (\%) & Symptom & Scion vol. (\%) \\
\hline Control & NS & 100 & NS & 100 \\
\hline + CVd-IIa & $\mathrm{BC}$ & 70 & NT & NT \\
\hline$+\mathrm{CVd}$-IIIb & $\mathrm{FI}+\mathrm{BS}$ & 40 & NS & 100 \\
\hline
\end{tabular}

a NS, nonsymptomatic; BC, bark cracking; NT, not tested; FI, finger imprint; BS, bark striations.

The symptom of bark cracking bears no similarity to finger imprint and has been previously reported (13) in the absence of any evidence of finger imprint symptoms.

\section{DISCUSSION}

Host specificity among citrus viroids can be used to describe a divergent range of plant pathogens. The widespread occurrence of hop stunt viroid related viroids, including CVd-II, across numerous plant families and throughout the world is documented $(1,9,14)$. To the contrary, CVd-III displays essentially an exclusive relationship with citrus species similar to the restriction of Avocado sunblotch viroid to avocado (16).

Observation of the unique finger imprint symptom and the conditions required for this unusual symptom expression further emphasizes the pronounced specificity that exists between $P$. trifoliata and CVd-IIIb. The fact that the expression of this symptom appears to be dependent upon the interaction with a climatic factor, water, but only when applied in a specific manner, suggests a truly unusual relationship among host, pathogen, and environment.

No visual correlation could be made between the initial site of graft inoculation of the rootstock and the locus of appearance of finger imprints. One might speculate that expression of the finger imprint symptom may be in some manner associated with the localized site of initiation of infection, replication, and accumulation of CVd-IIIb in the vascular tissue of the bark (23). Data presented here suggest that viroid titer is lower in symptom-expressing tissues than in adjacent normal appearing bark. The forceful application of water in a highly directed manner may have resulted in differential and localized cooling of tissues expressing finger imprints. This may be related to the well-accepted observation that high temperatures favor viroid replication and accumulation.

A further consideration might be that the seasonal period for application of supplemental water coincides with the time of maximum cambial activity in citrus (15). The metabolic and developmental properties of these tissues may be affected in an asymmetric manner by sprinkler irrigation. It might be further speculated that the developmental aberrations occur within the vascular tissue and affect the movement of phytohormones required for normal plant growth and already shown to be involved in viroid pathogenesis (4).

Dwarfing of citrus scions on P. trifoliata rootstocks containing $\mathrm{CVd}-\mathrm{III}$ b has been demonstrated in many citrus growing areas $(6,18,20-22)$. Although a canopy reduction of $60 \%$ was recorded for trees on P. trifoliata with $\mathrm{CVd}$-IIIb displaying finger imprints and bark striations, this level of dwarfing has been previously observed with several scions in the absence of any symptoms $(18,19)$. The specificity of the dwarfing response is supported by the lack of a similar response in citrange, a trifoliate hybrid rootstock. It is interesting that in studies of the dwarfing of trees on trifoliate rootstocks by CVd-IIIb, the first indication of reduced tree size does not become apparent until 5 years postinoculation. Furthermore, inoculation of CVd-IIIb into mature trees has no effect on tree size, and even delaying inoculation for 3 years diminishes the dwarfing response. This would suggest that the metabolic and developmental events that result in dwarfing response must be initiated within this early period of tree maturation. The time factor of 5 years of field growth required for the appearance of finger imprint symptoms has a strikingly similar temporal pattern.

Although the dwarfing response of trifoliate rootstock to $\mathrm{CVd}$-IIIb is not usually associated with finger imprint appearance, this symptom perhaps may present an exaggerated expression of processes induced in infected plant metabolism related to dwarfing. The appearance of finger imprint may be a more apparent expression of a developmental aberration that occurs under the conditions described here. Thus, the appearance of the finger imprint symptom presents a highly unusual complex relationship of a specific host, $P$. trifoliata, a specific viroid, CVd-IIIb, the climatic factor, water, and a specific cultural practice, sprinkler irrigation.

\section{ACKNOWLEDGMENTS}

We thank Walt Stutzman of the University of California, Lindcove Research and Extension Center, and G. Greer and R. Serna from the Citrus Clonal Protection Program for assistance with plant materials. Our special thanks to Judy A. Szychowski for assistance with collecting field data and manuscript review and to Toan Khuong for preparation of illustrations.

\section{LITERATURE CITED}

1. Amari, K., Gomez, G., Myrta, A., Di Terlizzi, B., and Pallas, V. 2001. The molecular charac- terization of 16 new sequence variants of hop stunt viroid reveals the existence of invariable regions and a conserved hammerhead-like structure on the viroid molecule. J. Gen. Virol. 82:953-962.

2. Ashulin, L., Lachman, O., Hadas, R., and BarJoseph, M. 1991. Nucleotide sequence of a new viroid species, citrus bent leaf viroid (CBLVd) isolated from grapefruit in Israel. Nucleic Acids Res. 19:4767.

3. Duran-Vila, N., Roistacher, C. N., RiveraBustamante, R., and Semancik, J. S. 1988. A definition of citrus viroid groups and their relationship to the exocortis disease. J. Gen. Virol. 69.3069-3080.

4. Duran-Vila, N., and Semancik, J. S. 1982. Differential response of tomato tissue infected with the citrus exocortis viroid to exogeneous auxins. Phytopathology 72:777-781.

5. Duran-Vila, N., and Semancik, J. S. 2003. Citrus viroids. Pages 178-194 in: Viroids. A Hadidi, R. Flores, J. W. Randles, and J. S. Semancik, eds. CSIRO Publishing, Collingwood, Vic, Australia.

6. Gillings, M. R., Broadbent, P., and Gollow, B. I. 1991. Viroids in Australian citrus: Relationship to exocortis, cachexia and citrus dwarfing. Aust. J. Plant Physiol. 18:559-570.

7. Gross, H. J., Krupp, G., Domdey, H., Raba, M., Jank, P., Lossow, C., Alberty, H., Ramm, K., and Sanger, H. L. 1982. Nucleotide sequence and secondary structure of citrus exocortis and chrysanthemum stunt viroids. Eur. J. Biochem. 121:249-257.

8. Hadas, R., Ashulin, L., and Bar-Joseph, M. 1992. Transmission of a citrus viroid to avocado by heterologous grafting. Plant Dis. 76:357-359.

9. Kofalvi, S. A., Marcos, J. F., Canizares, M. C., Pallas, V., and Candresse, T. 1997. Hop stunt viroid (HSVd) sequence variants from Prunus species: Evidence for recombination between HSVd isolates. J. Gen. Virol. 78:3177-3186.

10. Madaluni, A. L. 1968. Studies on finger mark disorder of citrus in Italy. Pages 10-13 in: Proc. Conf. IOCV, 4th. University of Florida, Gainesville.

11. Palacio-Bielsa, A., Foissac, X., and DuranVila, N. 1999. Indexing of citrus viroids by imprint hybridization. Eur. J. Plant Pathol. 105:897-903.

12. Rakowski, A. G., Szychowski, J. A., Avena, Z. S., and Semancik, J. S. 1994. Nucleotide sequence and structural features of the Group III citrus viroids. J. Gen. Virol. 75:3581-3584.

13. Roistacher, C. N., Bash, J. A., and Semancik, J. S. 1993. Distinct disease symptoms in Poncirus trifoliata induced by three citrus viroids from three specific groups. Pages 173-179 in: Proc. Conf. IOCV, 12th. IOCV, Riverside, CA.

14. Sano, T., Hataya, T., Terai, Y., and Shikata, E. 1989. Hop stunt viroid strains from dapple fruit disease of plum and peach in Japan. J. Gen. Virol. 70:1311-1319.

15. Schneider, H. 1968. The anatomy of Citrus. Pages 1-6 in: The Citrus Industry, Vol. 2. W. Reuther, L. D. Batchelor, and H. J. Webber, eds. University of California, Berkeley.

16. Semancik, J. S. 2003. Avocado sunblotch viroid. Pages 171-177 in: Viroids. A. Hadidi, R. Flores, J. W. Randles, and J. S. Semancik, eds. CSIRO Publishing, Collingwood, Vic, Australia.

17. Semancik, J. S., Bash, J., and Gumpf, D. J. 2002. Induced dwarfing of citrus by transmissible small nuclear RNA (TsnRNA). Pages 390-394 in: Proc Conf. IOCV, 15th. IOCV, Riverside, CA.

18. Semancik, J. S., Rakowski, A. G., Bash, J. A., and Gumpf, D. J. 1997. Application of selected viroids for dwarfing and enhancement of production of "Valencia" orange. J. Hortic. Sci. 72:563-570.

19. Semancik, J. S., Roistacher, C. N., RiveraBustamante, R., and Duran-Vila, N. 1988. Cit- 
rus cachexia viroid, a new viroid of citrus: Relationship to viroids of the exocortis disease complex. J. Gen. Virol. 69:3059-3068.

20. Tessitori, M., La Rosa, R., Di Serio, F., Albanese, G., and Catara, A. 2002. Molecular characterization of a citrus viroid III (CVd-III) associated with citrus dwarfing in Italy. Pages
387-389 in: Proc Conf. IOCV, 15th. IOCV, Riverside, CA

21. Verniere, C., Botella, L., Dubois, A., Chabrier, C., and Duran-Vila, N. 2002. Properties of citrus viroids: Symptom expression and dwarfing. Pages 240-248 in: Proc Conf. IOCV, 15th. IOCV, Riverside, CA.
22. Villalobos, W., Rivera, C., and Hammond, R. 1997. Occurrence of citrus viroids in Costa Rica. Rev. Biol. Trop. 45:983-987.

23. Zhu, Y., Green, L., Woo, Y.-M., Owens, R., and Ding, B. 2001. Cellular basis of potato spindle tuber viroid systemic movement. Virology 279:69-77. 